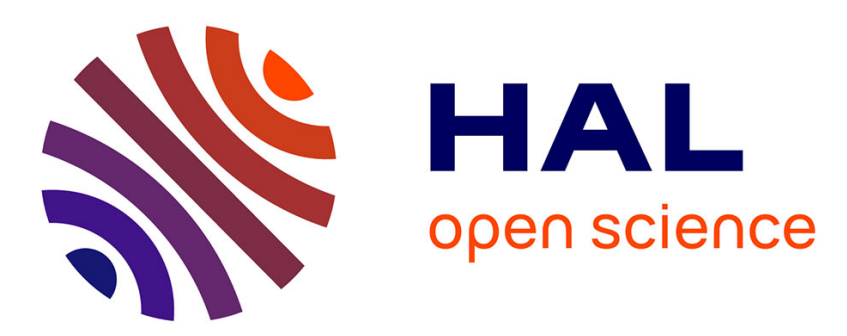

\title{
Metal Ions and Complexes in Alzheimer's Disease: From Fundamental to Therapeutic Perspectives
}

Christelle Hureau

\section{To cite this version:}

Christelle Hureau. Metal Ions and Complexes in Alzheimer's Disease: From Fundamental to Therapeutic Perspectives. R. A. Scott. Encyclopedia of Inorganic and Bioinorganic Chemistry, John Wiley \& Sons, Ltd, pp.1-14, 2019, 9781119951438. 10.1002/9781119951438.eibc2635 . hal-02185708

\section{HAL Id: hal-02185708 \\ https://hal.science/hal-02185708}

Submitted on 17 Dec 2020

HAL is a multi-disciplinary open access archive for the deposit and dissemination of scientific research documents, whether they are published or not. The documents may come from teaching and research institutions in France or abroad, or from public or private research centers.
L'archive ouverte pluridisciplinaire HAL, est destinée au dépôt et à la diffusion de documents scientifiques de niveau recherche, publiés ou non, émanant des établissements d'enseignement et de recherche français ou étrangers, des laboratoires publics ou privés. 


\section{Metal ions and complexes in Alzheimer diseases: from fundamental to therapeutic perspectives}

Christelle Hureau,

LCC-CNRS, Université de Toulouse, CNRS, Toulouse, France

Christelle.hureau@lcc-toulouse.fr

\section{SOMMAIRE}

I. Inorganic chemistry of the amyloid- $\beta$ peptides

Introduction to intrinsically disordered peptides.

Alzheimer's Disease.

The various forms of $A \beta$ peptides.

Metal ions: copper and zinc in the synaptic cleft.

Coordination to the $A \beta$ peptides.

ROS.

Aggregation.

Generalization to others IDPs.

\section{Therapeutic approaches linked in AD}

Chelators.

Metallophores.

Prod-drugs.

Inorganic drugs.

Inorganic detection agents.

Concluding remarks.

\section{What's next?}

Note: due to the large literature on the topic, the references quoted in the manuscript have been limited to works published during the last 10 years. 


\section{Inorganic chemistry of the amyloid- $\beta$ peptides}

Introduction to intrinsically disordered peptides. Intrinsically disordered proteins/peptides (IDPs) are biologically active proteins without stable tertiary structure, whose functions are multiple and complete those of the ordered proteins, being commonly related to recognition, as well as control and regulation of various signaling pathways. ${ }^{1}$ When dysregulated and/or dysfunctional, IDPs become key players of several human diseases, including neurodegenerative disorders such as Alzheimer's disease (AD). ${ }^{2}$ Actually, due to their high plasticity and flexibility, they can indeed be involved in functions, malfunctions or dysfunctions. In the present review, I will focus on the dysfunction of the IDP amyloid- $\beta(A \beta)$ peptide involved in AD.

IDPs are characterized by their propensity to form amyloid structures. Amyloids are selfaggregated peptides or proteins considered as a signature of neurodegenerative diseases. ${ }^{3}$ However, they represent a fundamental non-pathological structure utilized by living organisms, from bacteria to humans. ${ }^{4}$ Amyloids are a bundle of highly ordered filaments composed of ladders of $\beta$-strands (i.e. $\beta$-sheets) perpendicular to the fiber axis. The stability of such a three-dimensional organization is attained through several types of non-covalent bonds, mainly hydrogen bonds but also hydrophobic and $\pi-\pi$ stacking interactions. Amyloids are the most stable form of any kind of peptides and proteins, and the 3D structures of ordered protein corresponds to metastable states of the proteins (Figure 1). ${ }^{5}$ Fibrils are the dead-end point of the aggregation process that will be discussed more deeply later on.

A relatively well conserved feature of amyloid-related diseases is the presence of loosely bound metal ions, i.e. metal ions that are not strongly bound to biomolecules and that can be exchanged rapidly between biomolecules, in the area where the amyloid deposits occurs. ${ }^{5-9}$ In line with the presence of redox-active metal ions in the amyloid deposits, oxidative stress is often encountered in amyloid-related diseases, although the importance of direct metal-induced Reactive Oxygen Species (ROS) to the overall oxidative stress is still unclear. ${ }^{9-13}$ 


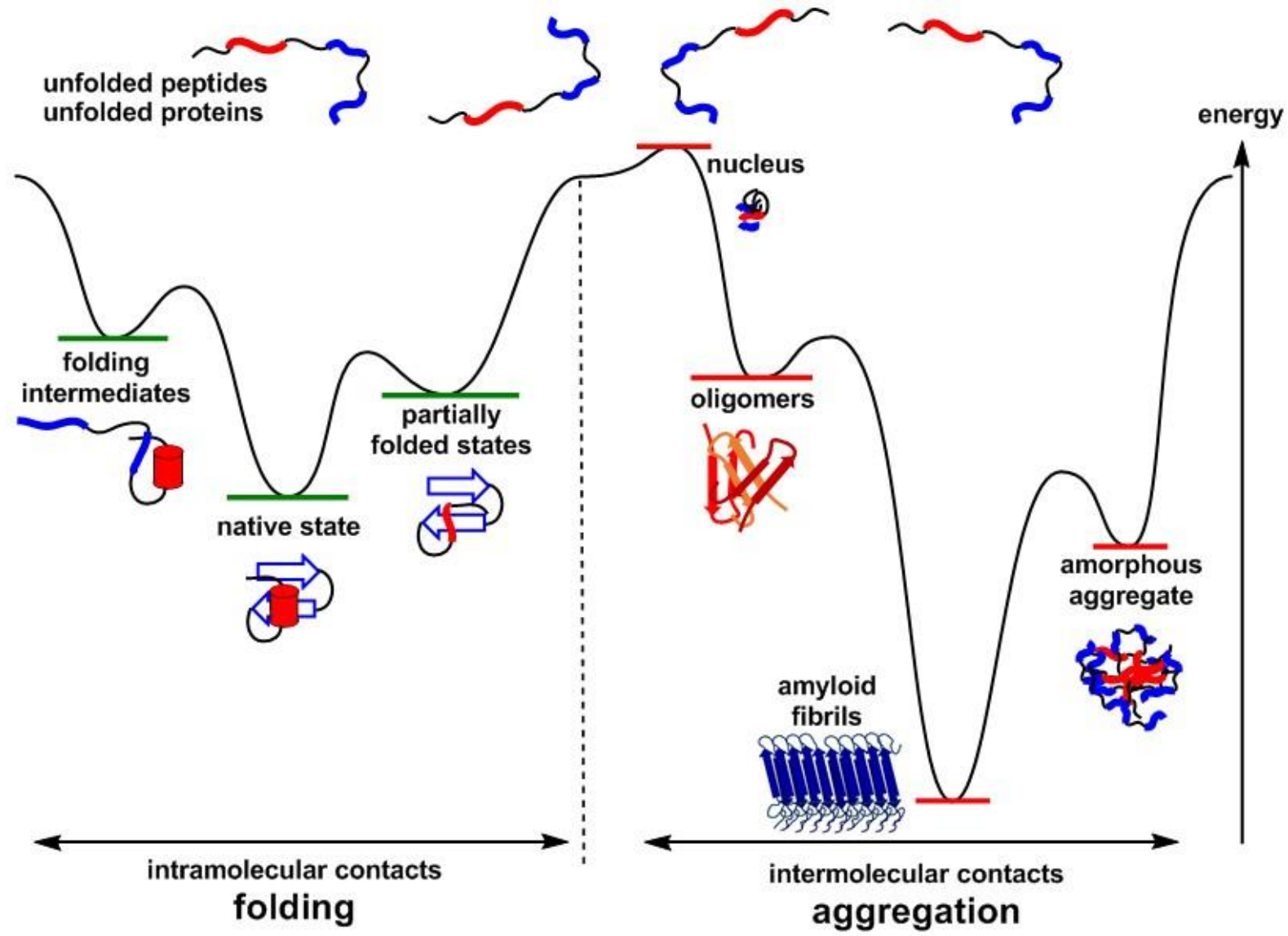

Figure 1. The energetic profile of folding versus aggregation of proteins. All proteins when misfolded can form amyloid fibrils. Chaperones act so as to help the proper folding of proteins. ${ }^{14}$ IDPs follow the aggregation pathway (see further details of aggregation kinetics in the Aggregation section).

In this review, we will illustrate the inorganic chemistry of IDPs following the example of the $A \beta$ peptide encountered in AD. A first part is dedicated to the interaction of metal ions with IDPs and to the consequences with respect to aggregation and ROS production and a second part focuses on the various strategies developed to counteract such metal ions to $A \beta$ interactions.

Alzheimer's Disease. $A D$ is a neurodegenerative disorder characterized by progressive cognitive and memory impairment and is the most common cause of dementia in the elderly population, accounting for $60-80 \%$ of dementia cases. ${ }^{15,} 16$ The prevalence of $A D$ is expected to double every 20 years in the near future and thus the social and economic burden of AD will continue to grow. ${ }^{17}$ This trend is mainly due to the increase of life expectancy and to the absence of curative medications. At the microscopic scale, $A D$ is characterized by two hallmarks: the intra-cellular neurofibrillary tangles of hyperphosphorylated Tau protein ${ }^{18}$ and the extra-cellular senile plaques, made of aggregated $A \beta$ peptides. ${ }^{19-21}$ In the amyloid deposits, metal ions, mainly $\mathrm{Cu}, \mathrm{Zn}$ and Fe are found at $\mathrm{mM}$ concentrations and while Fe is mainly present as co-localized nanoparticles, $\mathrm{Cu}$ and $\mathrm{Zn}$ are bound to the $A \beta .22-24$ 
The various forms of $A \beta$ peptides and the amyloid cascade hypothesis. The $A \beta$ peptide is not unique: there are many forms (sequences) of the $A \beta$ peptides, with various lengths and key point modifications. $A \beta$ peptides are obtained from the cleavage of the Amyloid Precursor Protein by the $\beta$ - and $\psi$-secretase..$^{25}$ The most well-known and studied forms of $A \beta$ are the "full-length" peptides made of 37 to 43 amino-acid residues (noted $A \beta_{1-37 / 43}$, see the abbreviations paragraph for the notation of the peptides) with the two predominant forms being the $A \beta_{1-40 \text { and }} A \beta_{1-42}$. The sequence of the $A \beta_{1-43}$ is shown in Figure 2 along with the most important mutations or peptide alterations. Indeed there is some heterogeneity at both the $\mathrm{N}$-terminal and the $\mathrm{C}$-terminal cleavage sites, leading to peptides with C-terminal side ending between residues 37 and 43 and $\mathrm{N}$-terminal side starting between residues 1 and 5 and at residue 11. In addition, there are the pyroglutamate counterparts of the $A \beta_{3-n}$ and $A \beta_{11-n}$ and mutants responsible for the early onset of $A D$ (known familial mutants). Murine animals also have a modified form of the peptide with mutations at positions 5 (R5G), 10 (Y1OF) and 13 (H13R). ${ }^{26}$ It is anticipated that the various forms of the $A \beta$ peptides interact differently with the metal ions, especially when the modified residues belong to the family of the binding residues (the terminal amine, the His, Asp and Glu side chains). ${ }^{27,}{ }^{28}$ Alterations can also cause a modification in the secretase activities and thus in peptides processing and release, leading to an increase of the $A \beta_{1-42}$ over $A \beta_{1-40}$ ratio. ${ }^{26}$ As the longer $A \beta_{1-42}$ form is more prone to aggregation than $A \beta_{1-40}$, an increase of this ratio documents the hypothesis according to which aggregation is a key and deleterious process in $A D$ development, known as the amyloid cascade hypothesis. ${ }^{29}$ According to this hypothesis, aggregation of the $A \beta$ peptide is the early event in the disease that results in Tau dysfunction, neuronal loss and ultimately dementia. Familial AD (FAD) modifications of the peptide leading to early onset of the disease are also involved either in modulation of the secretase activity, or enhancement of the aggregation propensity of the peptide, once again nourishing the amyloid cascade hypothesis. ${ }^{15}$

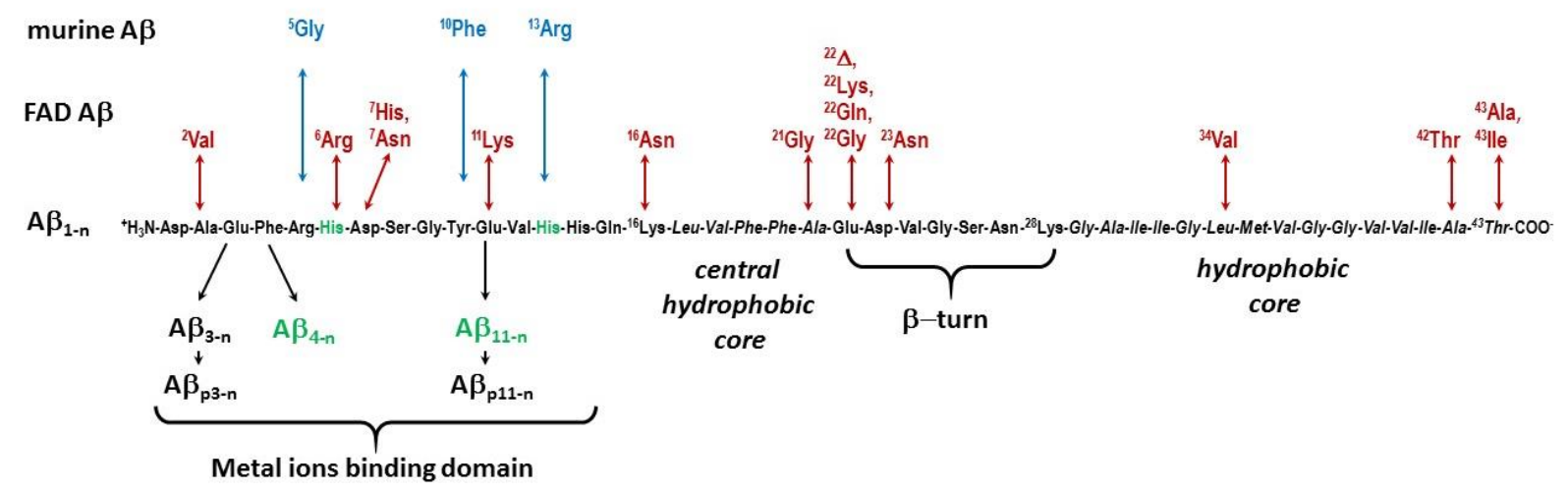

Figure 2. Sequences of the various $A \beta$ peptides using the three-letter code of amino-acids. In green: truncation leading to the ATCUN motif with the His in third position drawn in green; in red: FAD mutations; in blue: mutations leading to murine peptide. 
Metal ions: copper and zinc in the synaptic cleft. $A D$ takes place in the synaptic cleft, a place of intense metal ion exchange. More precisely, a subset of glutamatergic neurons contains high amounts of $\mathrm{Zn}(\mathrm{mM})$ in their synaptic vesicles. $\mathrm{Zn}$ is transported via the $\mathrm{ZnT3}$ transporter into these vesicles. Upon neuronal activation, these vesicles fuse with the cell membrane and $\mathrm{Zn}$ is released in the synaptic cleft. Locally, transient concentrations of up to several $100 \mu \mathrm{M}$ have been detected. $\mathrm{Zn}$ is then rapidly taken up again by the neurons. It has been shown that this $\mathrm{Zn}$-pool, released from neurons, plays a neuromodulatory role. Evidence from the literature suggests that $\mathrm{Cu}$ pumped by the ATPase7A Cu-transporter into vesicles could be released into the synaptic cleft via vesicle fusion. The oxidation state of vesicular $\mathrm{Cu}$ and its ligand(s) are not known. It is thus anticipated that the $\mathrm{Zn}$ and $\mathrm{Cu}$ exchanged in the synaptic cleft interact with $A \beta$ and are finally found in high concentrations in the senile plaques detected in AD brains (Figure 3). ${ }^{30,31}$

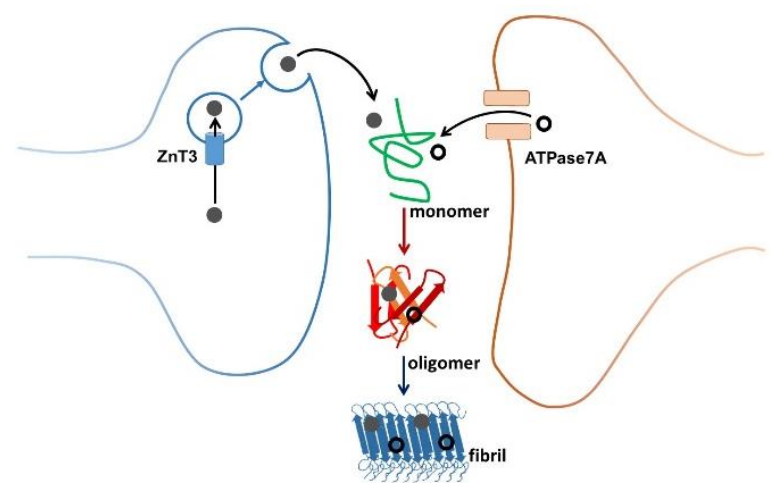

Figure 3. Zinc (plain grey circles) and copper (open black circles) movements in the synaptic cleft and aggregation of the $A \beta$ peptides leading to the amyloid fibrils found in the senile plaque, via the formation of oligomeric species considered as the most toxic ones.

Coordination to the $A \beta$ peptides. Because the metal ions may interact with $A \beta$ peptides, the coordination abilities (i.e. sites, affinity and kinetics of binding) of the $A \beta$ peptides with respect to $\mathrm{Cu}(\mathrm{I})$ and $\mathrm{Cu}(\mathrm{II})$ and $\mathrm{Zn}(\mathrm{II})$ have been intensively studied in the last decade, although mainly the "fulllength" peptides were under investigations.

Cu(II) - Coordination sites. $\mathrm{CU}$ (II) has first and mainly been under focus. This may be because of its $d^{9}$ electronic configuration that makes it active in many spectroscopies (EPR (see eibc.0310), NMR, UV-Vis and CD). ${ }^{9}, 27,32,33$ In addition, the study of $\mathrm{Cu}(\mathrm{II})$ binding site to $A \beta$ has fostered the development of sophisticated techniques and methodologies. ${ }^{27,32} \mathrm{Cu}(\mathrm{II})$, as with other metal ions, are bound to the $\mathrm{N}$-terminal part encompassing the 14 first residues and is bound to the $A \beta$ via the $\mathrm{N}$ terminal amine, two among the three His residues and one carbonyl function from the peptide backbone, with a preference for the carbonyl group of Asp1-Ala2 bond. This site (site I) is the most 
populated at physiological $\mathrm{pH}$ but is in $\mathrm{pH}$ equilibrium with a second one (site II) where the $\mathrm{Cu}(\mathrm{II})$ ion is bound by the N-terminal amine, the adjacent amidate function from the Asp1-Ala2 bond and carbonyl group from Ala2-Glu3 and one among the three His residues. The $\mathrm{Cu}(\mathrm{II})$ adopts its preferred binding geometry, induced by the Jahn-Teller effect, with four equatorial ligands and a fifth apical position that may be occupied by carboxylato groups. Coordination of $\mathrm{Cu}(\mathrm{II})$ to $A \beta_{1-n}$ and to other selected forms of $A \beta$ are given in Figure 4. Notably, the $A \beta_{4 / 11-n}$ peptides offer the $C u(I I)$ an ATCUN (Amino-Terminal $\mathrm{Cu}$ and $\mathrm{Ni}$ binding motif) site which is due to the $-\mathrm{H}_{2} \mathrm{~N}-\mathrm{Xxx}-\mathrm{Yyy}-\mathrm{H}$ is sequence, ${ }^{34} \mathrm{a}$ motif that is shared with key proteins such as the Human Serum Albumin and has been strongly studied for its biological properties. ${ }^{35,}{ }^{36} \mathrm{Cu}(\mathrm{II})^{27}$ binding to the murine peptide (See Figure 2 for sequence) has also been investigated. Indeed as murine animals do not show AD, it is anticipated that different coordination sites may be responsible, at least in part, of the different amyloidogenicity of the two peptides.

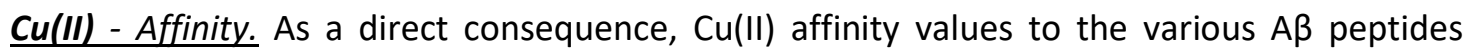
differs with $A \beta_{4 / 11-n}$ having the highest one: $10^{14} \mathrm{M}^{-1}$, the $A \beta_{1 / 3-n}$ intermediate : $10^{10} \mathrm{M}^{-1}$ and the

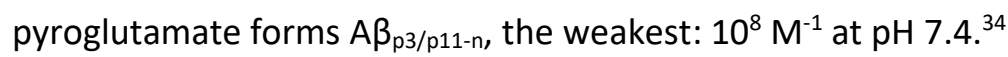

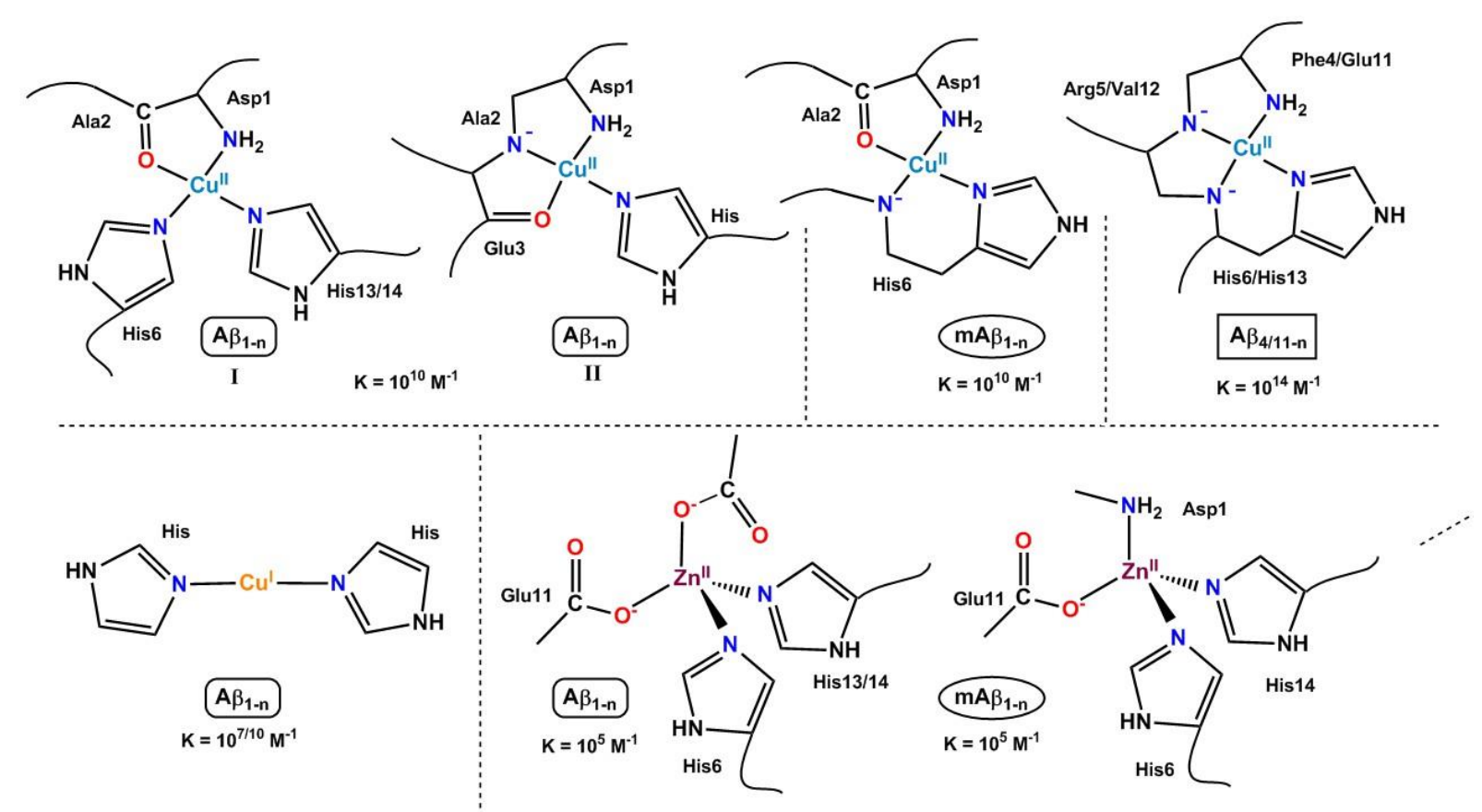

Figure 4. Metal ion coordination to several $A \beta$ peptides and corresponding conditional affinity value at $\mathrm{pH} 7.4$. Regarding $\mathrm{Cu}(\mathrm{I})$ affinity, the two most accepted values reported in the literature are given.

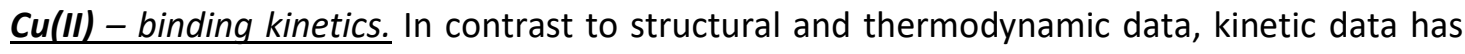
been less investigated and mainly with $A \beta_{1-n}$. The rate of $\mathrm{Cu}(\mathrm{II})$ binding $\left(\mathrm{k}_{\mathrm{on}}\right)$ is about $5 \times 10^{8} \mathrm{M}^{-1} \cdot \mathrm{s}^{-1} 37$ or $5 \times 10^{6} \mathrm{M}^{-1} \cdot \mathrm{s}^{-1},{ }^{38}$ where the weaker value may be due to the co-presence of glycine in the solution 
studied. ${ }^{39} \mathrm{Cu}$ (II) binding is much faster in site I than in site II so $\mathrm{Cu}(\mathrm{II})$ binding to site II goes through binding to site I and further reorganization. ${ }^{37-39}$ In addition, the $k_{\text {on }}$ value is not strongly dependent with peptide FAD alterations. ${ }^{40}$ Rate of $\mathrm{Cu}(\mathrm{II})$ dissociation from $A \beta_{1-n}\left(\mathrm{k}_{\text {off }}\right)$ has been evaluated to 0.1$0.8 \mathrm{~s}^{-1}, 37,38$ all the data being given at $\mathrm{pH} 7.4$.

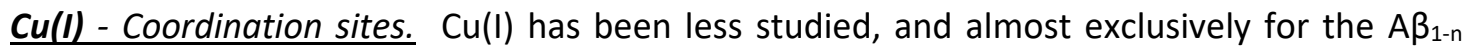
peptide, but the model of the coordination site was rapidly consensual, with two His making a linear His- $\mathrm{Cu}(\mathrm{I})$-His arrangement (Figure 4), where the most populated site was made by the two adjacent His13 and His14. 22, 41, 42 The result was mainly obtained using XANES spectroscopy (X-ray Absorption Near Edge Structure, see eibc.0305) since the intensity of the $1 \mathrm{~s}$ to $4 p$ edge feature is strongly characteristic of the coordination mode of $\mathrm{Cu}(\mathrm{I})$. It could be anticipated that any form of $A \beta$ keeping the His13-His14 dyad would show a similar $\mathrm{Cu}(\mathrm{l})$ site.

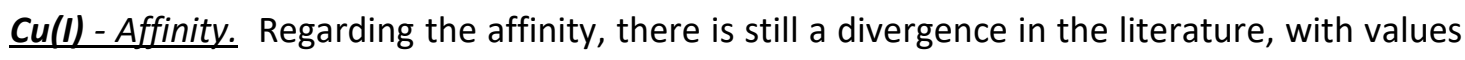
of $10^{7} \mathrm{M}^{-1}$ or $10^{10} \mathrm{M}^{-1}, 43-45$ due to a difference in the $\mathrm{Cu}(\mathrm{l})$ affinity value taken for the competitor used in the titration experiment; hence the need to find a more direct way to determine $\mathrm{Cu}(\mathrm{l})$ affinity.

$\underline{Z n(I I)}$ - Coordination sites. As for $\mathrm{CU}(\mathrm{I})$, the $\mathrm{d}^{10}$ electronic configuration of $\mathrm{Zn}$ (II) makes it silent in most of the classical spectroscopic techniques. In addition and in contrast to $\mathrm{Cu}(\mathrm{I})$, the XANES fingerprint is weakly informative. That's why several binding modes have been proposed. ${ }^{23,46}$ Recent results point to a $\mathrm{Zn}(\mathrm{II})$ ion tetrahedrally bound by two His residues and two carboxylates, with the predominant contribution of Glu11. ${ }^{47}$ The murine peptide shows a different site with a $\mathrm{Zn}$ (II) surrounded by the $\mathrm{N}$-terminal amine, two His side chains and the carboxylate group from Glu11 (Figure 4). ${ }^{48}$ Noteworthy, both the $\mathrm{Cu}(\mathrm{II})$ and $\mathrm{Zn}(\mathrm{II})$ major sites at physiological pH differ between human and murine peptides, with the general trend of having a less protonated peptide bound to the metal center with the murine $A \beta$. Several studies of $Z n(I I)$ coordination to FAD have been reported and pointed out to the facilitated formation of aggregation prone $\mathrm{Zn}$ complexes. ${ }^{49-51}$

$\underline{Z n(I I)}$ - Affinity. The $\mathrm{Zn}(\mathrm{II})$ affinity for $A \beta_{1-n}$ is largely weaker than $\mathrm{Cu}(\mathrm{II})$ affinity and lies in the $10^{5} \mathrm{M}^{-1}-10^{6} \mathrm{M}^{-1}$ range. $^{52,53}$

Concluding remarks. Recurrent features in all the binding sites made by the $A \beta$ peptides are (i) the presence of several sites, which are due to several equilibria in solution including $\mathrm{pH}$ equilibria; (ii) the nature of the binding site is dictated by the central ion; in other words, the peptide is unable to offer a preorganized binding site as encountered with 3D-folded metalloproteins. This may be due to two factors: the high flexibility of the peptide and the number of potential binding amino-acid residues which exceeds the coordination number of the metal center, thus allowing the metal ion to 
choose its preferred environment. A direct consequence is the impossibility to get structural data by X-ray crystallography; hence the multi-technic approach used to determine metal binding sites in $A \beta$.

ROS. One key impact of $\mathrm{Cu}(\mathrm{I}) / \mathrm{Cu}(\mathrm{II})$ binding to $A \beta$ is the production of ROS, which results from the incomplete reduction of $\mathrm{O}_{2}$ to $\mathrm{O}_{2}^{\circ}, \mathrm{H}_{2} \mathrm{O}_{2}$ and $\mathrm{HO}^{\circ}$ by ascorbate catalyzed by $\mathrm{Cu}(\mathrm{A} \beta$ ) (Figure 5, left panel). Given the very different binding sites of the two redox states of $\mathrm{Cu}$, a direct electronic transfer will necessitate a very high reorganization energy, extremely unfavorable for the catalysis. Hence it has been proposed that the redox reactions proceed via another site, the geometry of which is between that of $\mathrm{Cu}(\mathrm{I})$ and $\mathrm{Cu}(\mathrm{II})$ and is the same for both $\mathrm{Cu}(\mathrm{I})$ and $\mathrm{Cu}(\mathrm{II})$ ions. This site is known as the "in-between state" (IBS) ${ }^{22}$ and was first observed via electrochemistry, ${ }^{54}$ hence without any external substrate (reductant or oxidant). Further studies in presence of substrate led to the proposition of $\mathrm{Cu}$ ions bound by the $\mathrm{N}$-terminal amine and the carboxylate side chain from Asp1 and from one His residue, and indicated that the rate-limiting step of the complete redox cycle may be due to oxidation of $\mathrm{Cu}(\mathrm{I})$ by dioxygen. ${ }^{55}$ This IBS has only been proposed for $A \beta_{1-n}$ but similar states may also be encountered with the other forms of $A \beta$ since for all $A \beta$, the $\mathrm{Cu}(\mathrm{I})$ and $\mathrm{Cu}(\mathrm{II})$ coordination environments are extremely different.

Aggregation. The formation of amyloids follows a specific pathway consisting in the aggregation of largely unfolded monomeric units, according to a two-step process: a rate-limiting nucleation phase during which oligomers form and an elongation phase during which the fibrils are made via the auto-catalytic self-assembly of peptides triggered by the oligomers (Figures 1 and 5). ${ }^{34,}$ ${ }^{56,57}$ It is now accepted that the transient oligomeric species are the most toxic. ${ }^{58}$ Aggregation of apo$A \beta$ follows the sigmoid-type curve as probed by thioflavin T (ThT), a dye that acquires fluorescence upon binding to $\beta$-sheet structures ${ }^{56}$ and lead to well-defined typical amyloid fibrils (diameter of about $10 \mathrm{~nm}$ and length of about $1 \mu \mathrm{m}$ ). Metal ions can influence this aggregation mechanism via several paths, including helping to bridge two monomers and to form the nucleus or inducing a change of the peptide to a conformation more prone to aggregation. ${ }^{59-61}$ The influence of $\mathrm{Cu}(\mathrm{II})$ and $\mathrm{Zn}$ (II) on $A \beta$ aggregation has mainly been investigated on the full-length $A \beta_{1-40 / 42}$ peptides with no real consensus. ${ }^{60,62}$ This is due to the intrinsic auto-catalytic character of the aggregation process, which is mainly governed by the nucleation phase. Several parameters that are difficult to fully identify and control influence the nucleation phase. One key parameter is the nature of the starting $A \beta$ sample, the perfect monomerization of which is required to get reproducible data. Then aggregation will depend on the conditions including concentration, buffer, $\mathrm{pH}$, ionic strength, the nature of metal ions and their ratio. ${ }^{63}$ With respect to the role of metal ions, the consensual general trends reported are: (i) stoichiometric amount of $\mathrm{Cu}(\mathrm{II})$ and $\mathrm{Zn}$ (II) influences $A \beta$ aggregation differently, with Zn(II) leading to the formation of ill-defined heterogeneous aggregates and CU(II) to 
small protofibrils; (ii) at weaker ratios, both $\mathrm{Cu}$ (II) and $\mathrm{Zn}$ (II) mainly influence the kinetics of the aggregation by delaying the elongation phase but keep the morphology of the apo-aggregates. ${ }^{33}$ Very recently, one structure of $A \beta_{1-42}$ fibrils has been proposed based on cryo-Electronic Microscopy, ${ }^{64}$ complementing previous propositions made by NMR. ${ }^{65,66}$ It shows the participation of binding residues from the $\mathrm{N}$-terminal part in several salt bridges; then it can be anticipated that such interaction will be disrupted by coordination of metal ions, explaining why metal ions do alter the full-length $A \beta$ aggregation.

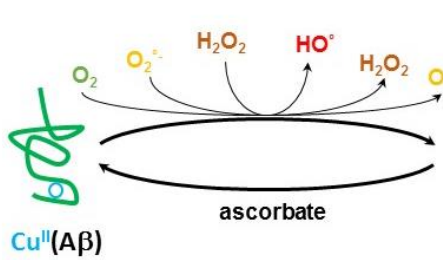

Cu'(AB)

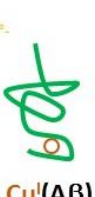

$\mathrm{Cu}^{\prime}(\mathbf{A} \beta)$

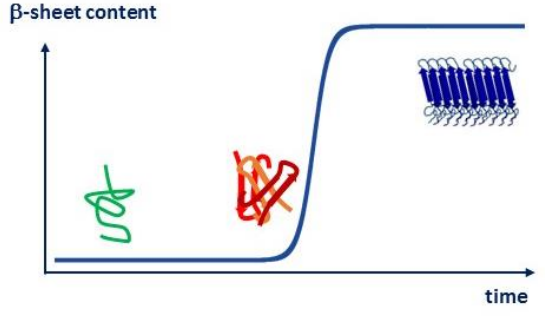

Figure 5. Left panel: ROS production catalyzed by the $\mathrm{Cu}\left(A \beta_{1-n}\right)$ species; right panel: the typical sigmoidal curve depicting the formation of $A \beta$ fibrils.

The coordination sites of metal ions in the solid state (full-length $A \beta$ aggregates) is very similar to those found for the soluble monomeric counterpart. ${ }^{22,67}$ This may be due to the flexibility of the $\mathrm{N}$-terminal site even in the solid-state.

Concluding remarks. It would be very interesting to explore in the near future (i) the ROS and aggregation properties at the molecular level of the altered counterparts of the $A \beta_{1-40 / 42}$, exploiting the tools and methods developed in the study of the full-length peptides. This has been partly done for N-terminally truncated forms ${ }^{34}$ and FAD peptides; and (ii) the ROS production mechanism by the oligomeric species to possibly link their toxicity to the ROS production.

Generalization to others IDPs. Other IDPs are involved in diverse neurodegenerative disorders. This is the case of the Tau protein in AD, ${ }^{18,19,31,68-70}$ of synucleins in Parkinson's Disease, ${ }^{8,9}$, ${ }^{70-74}$ of prion protein in Creutzfeld-Jacob Disease, ${ }^{8,74-76}$ polyGlu sequences in Huntington's Disease, ${ }^{77}$, 78 and $\mathrm{Cu}, \mathrm{Zn}$ superoxide dismutase (SOD) in amyotrophic lateral sclerosis. ${ }^{9,}$ 78-80 IDPs can also be linked to other (non-neurodegenerative) pathologies: for instance, amylin is involved in Type II Diabetes Mellitus. ${ }^{81-83}$ General features of those IDPs shared with the $A \beta$ peptides are: (i) formation of amyloid deposits [always]; (ii) presence of loosely bound metal ions in the vicinity of the deposits [frequent]; (iii) trace of oxidative stress [frequent]; (iv) familial mutations linked to early-onset of the 
disease [frequent] and mutations in the murine peptide counterpart which precludes the spontaneous apparition of the pathology [often].

Because the coordination of metal ions are governed by the same requirements as for the $A \beta$ peptide, similar consequences with respect to ROS production and aggregation can be foreseen. The literature is however more limited compared to that for $A \beta$ (see previous refs.). 


\section{Therapeutic approaches linked in AD}

Introducing remarks. As previously detailed, metal ions have important roles in the modulation of the intrinsic properties of the IDPs. In general, interaction of the IDPs with metal ions are considered harmful, leading to therapeutic approaches mainly based on the removal of the metal ions. However, this raises several questions: (i) Is it safe to remove metal ions ? (ii) should both $\mathrm{Cu}$ and $\mathrm{Zn}$ be removed ? (iii) what can be the alternatives ?

In the following paragraphs, we describe the various inorganic approaches reported in the context of curing AD. We limit the description to AD because it is a prototypical IDP-related disease with respect to inorganic based therapies. This will include the molecules able to target metal ions or inorganic complexes able to interfere with ROS production and/or $A \beta$ aggregation. Finally, we will briefly show some use of inorganic complexes for the early detection of AD.

First, we start with the description of the various approaches to extract metal ions from the $A \beta$ peptides. As for the more fundamental studies, all the reports concerned the $A \beta_{1-n}$ peptides. In addition, because Cu can be directly involved in ROS production, it is generally regarded as the target of choice and hence I will describe only $\mathrm{Cu}$ targeting molecules. In the following, chelators correspond to molecules able to remove metal ions and metallophores to chelators able to redistribute the chelated ions elsewhere. The literature being extremely abundant of this topic, only chosen examples are described (and recent reviews given in refs.). The criterion for such a selection could be either historical, the smartness of the concept carried, but not necessarily the best drug candidates in terms of short-term medical approval (id est pharmacologic properties).

Chelators. Note that among the chelators described here, some may also be metallophores as well but the property has not been challenged and/or reported. Most of the chelators designed target $\mathrm{Cu}(\mathrm{II})$ and to be able to remove it from $A \beta$ have higher $\mathrm{Cu}(\mathrm{II})$ affinity than the $A \beta$ peptide. Of course, the affinity should not be too high in order to maintain as much as possible the natural metal homeostasis. In addition to the ability to extract $\mathrm{Cu}$ from $A \beta$, most of the chelators are designed so as to redox silence the $\mathrm{Cu}$ ion and to prevent the formation of $\mathrm{Cu}$-induced oligomers. ${ }^{78,}{ }^{84-89}$ Extra activity and/or property are often sought leading to bi-functional and even multi-functional molecules. $^{90-93}$

Simple ligands. The simple cyclen (Figure 6.a) and cyclam scaffolds were probed for the above described abilities and show promising results. ${ }^{94}$ This is also the case for derivatives of Schiffbase ligands (Figure 6.b). ${ }^{95,} 96$ In particular, those ligands are able to selectively remove $\mathrm{Cu}(\mathrm{II})$ versus $\mathrm{Zn}$ (II) from the $A \beta$ peptide, a property that may be crucial as $\mathrm{Cu}(\mathrm{II})$ is the target of choice but that is 
not easy to fulfill due to (i) the high $\mathrm{Cu}(\mathrm{II})$ over $\mathrm{Zn}$ (II) selectivity of the $A \beta$ itself which is about 4 orders of magnitude while for standard ligands such as edta the selectivity is about 2 orders of magnitude and (ii) the excess of $\mathrm{Zn}$ compared to $\mathrm{Cu}$ in the synaptic cleft (ratio of about 10). ${ }^{33}$

Peptide-based ligands. The use of peptide-based molecules represents an interesting approach because the synthesis is highly modular. It is thus straightforward to adapt the affinity and/or to include additional groups such as a coumarin chromophore (Figure 6.c) that is able to act as a reporter for the extraction of $\mathrm{Cu}(\mathrm{II})$ from $A \beta \cdot{ }^{97}$

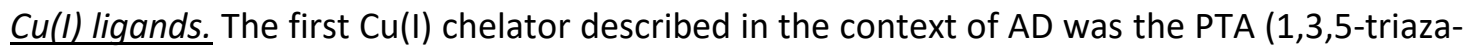
7-phosphaadamantane), Figure 6.d) a widely use molecule in anti-cancer therapy. ${ }^{98}$ Results were good with the ability to stop ROS production induced by $\mathrm{Cu}(\mathrm{A} \beta)$ and formation of oligomers. Later on, a more general approach was developed, where the ligand $L_{N T A}$ (Figure 6.e) was able to target both $\mathrm{Cu}(\mathrm{I})$ and $\mathrm{Cu}(\mathrm{II})$, remove them from $\mathrm{A} \beta$ and stop associated ROS production. ${ }^{99}$ The main interest of such an approach is its pragmatism since the redox state of $\mathrm{Cu}$ within the synaptic cleft is still unknown.

Bi- and multi-functional chelators. All the reported bi- and multi-functional chelators target $\mathrm{Cu}(\mathrm{II})$. Four examples of such molecules are given in Figure 6.a, f-h. As a classical feature, they encompass a $\mathrm{Cu}(\mathrm{II})$ binding moiety and a unit responsible for the recognition of $A \beta$ aggregates. Mainly three $A \beta$ recognition moieties are used: 2-aryl-benzothiazole (Figure 6.f), ${ }^{100}$ a scaffold reminiscent of the ThT dye known to interact with $\beta$-sheet (see §.Aggregation), stilbene-like derivatives (Figure 6.g) ) $^{101,102}$ and peptidic $\beta$-sheet breaker sequence, typically the KLVFF pentapeptide (Figure 6.a). ${ }^{103}$ The $A \beta$ recognition moiety can either encompass the binding groups (Figure 6.g) or be linked to it (Figure 6.a). A typical multifunctional chelator is given in Figure 6.h, where the binding motif is created by the formation of the triazole group obtained by the straightforward "click" reaction thus leading to a very high modularity of such drug candidates. ${ }^{104}$ 
a.<smiles></smiles>

cyclen

cyclen: $\mathrm{R}=\mathrm{H}$

cyc-KLVFF: R = KLVFF<smiles></smiles>

b.<smiles>[R]c1ccc(O)c(CN(C)CCN(C)Cc2cc([R])ccc2O)c1</smiles>

$\mathrm{GL}_{1}: \mathrm{R}_{1}=\mathrm{OGlu}$

$\mathrm{L}_{2}: \mathrm{R}=\mathrm{SO}_{3}{ }^{-}$ d.

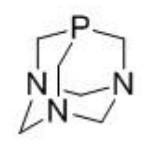

PTA e.<smiles>CNCCNC(=O)C(Cc1c[nH]cn1)NC(=O)CN(CC(=O)NC(Cc1c[nH]cn1)C(N)=O)CC(=O)NC(Cc1c[nH]cn1)C(N)=O</smiles>

h.<smiles>OCCn1cc(-c2ccccc2O)nn1</smiles>

Figure 6. Selection of chelators designed to fight against AD.

Metallophores. The most developed and studied family of metallophores is the hydroxyquinoline family (Figure 7.a). ${ }^{105}$ Clioquinol was first used and then the PBT2 derivative that offers a better pharmacologic profile was tested in Phase II of three different clinical trials. ${ }^{106}$ Mechanism of action of such molecules relies on their ability to translocate $\mathrm{Cu}$ and $\mathrm{Zn}$ into the neurons and to trigger several events including higher degradation of the $A \beta$ peptide. ${ }^{107}$ The other important class of metallophore is the bis(thiosemicarbazone) ligand (Figure7.b). Intracellular $\mathrm{Cu}$ transfer is mediated by the intracellular reduction of $\mathrm{Cu}(\mathrm{II})$ and subsequent release that triggers a cascade of biological events leading to better clearance of $A \beta$, in a similar way as proposed for hydroxyquinoline-based molecules. ${ }^{108} \mathrm{~A}$ bis-aminoquinoline ligand (Figure 7.c) has recently been shown to be able to transfer the $\mathrm{Cu}(\mathrm{II})$ extracted from $\mathrm{A} \beta$ to apo-proteins via the formation of an intermediate $\mathrm{Cu}(\mathrm{I})$-glutathione complex. ${ }^{109}$

a.<smiles>[R]c1ccc2c([R])cc([R])c(O)c2n1</smiles>

clioquinol: $\mathrm{R}_{1}=\mathrm{Cl}, \mathrm{R}_{2}=\mathrm{I}, \mathrm{R}_{3}=\mathrm{H}$

PBT2: $\mathrm{R}_{1}=\mathrm{R}_{2}=\mathrm{Cl} ; \mathrm{R} 3=\mathrm{N}\left(\mathrm{CH}_{3}\right)_{2}$ b.<smiles>CN/C(S)=N/N=C/C=N/NC(S)NC</smiles>

gtsm
C.<smiles>[R]N(c1ccc2cccc(N)c2n1)c1ccc2cccc(N)c2n1</smiles><smiles>[R]#CCCCCO</smiles>

$\operatorname{Bis}(A Q)$

Figure 7. Selection of metallophores designed to fight against AD. 
Prodrugs. An elegant way to avoid perturbing normal metal homeostasis is to design prodrugs that will release the active chelator at its place of action. ${ }^{110}$ The release can be triggered by different ways; three of them are illustrated below.

Cleavable peptide. A peptide encompassing a recognition site of the secretase involved in $A \beta$ processing is cleaved to deliver an ATCUN (see \&.Cu(II) coordination) motif able to strongly bind $\mathrm{Cu}(\mathrm{II})$, thus to remove it from $A \beta$ and redox silence it (Figure 8.a). ${ }^{111}$

Sugar-based ligands. Because the brain consumes a lot of sugar, glycosylated prochelators have been designed (Figure 8.b). In addition to masking the chelating unit, they can also direct the molecule towards its place of action and after enzymatic deprotection, the free ligand will be able to bind metal ions. ${ }^{112}$

Inorganic prodrug. Recently a Mn-based SOD mimic has been used to mask the chelator and was shown to redox silence $\mathrm{Cu}(\mathrm{II})$ extracted from $A \beta$ and restore apo-like aggregation of the peptide (Figure 8.c). ${ }^{113}$ This strategy has also the benefit to provide a prodrug active against the oxidative stress that occurs in AD.

a.

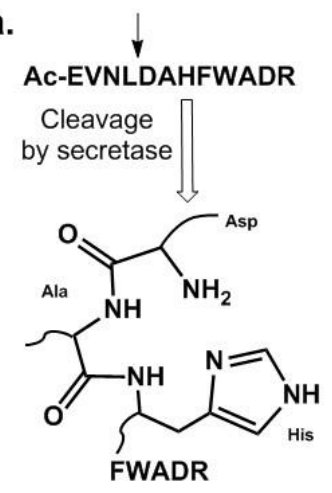

b.

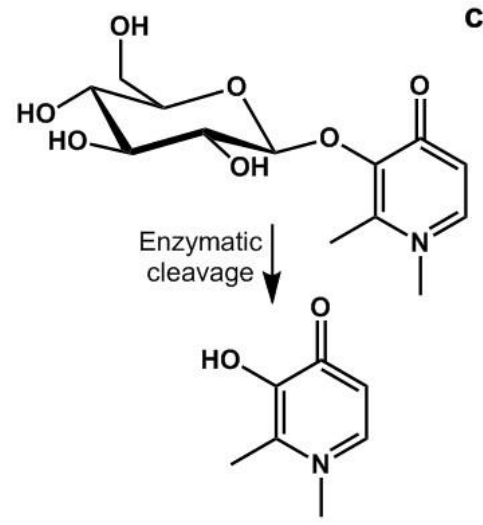

c.

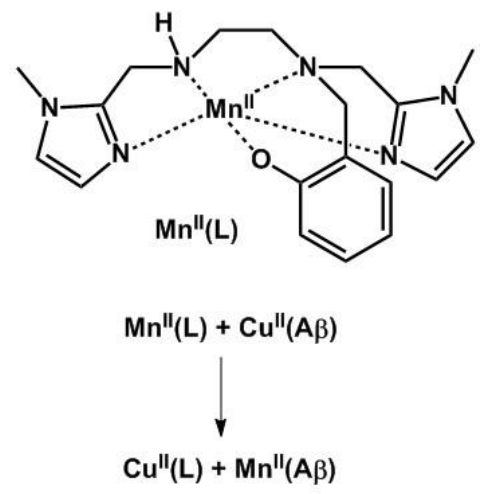

Figure 8. Prochelator approaches developed to fight AD.

Concluding remarks. Several key properties can be extracted from the studies detailed above:

(i) $\mathrm{A} C \mathrm{Cu}$ affinity higher than that of the $\mathrm{A} \beta$ peptides but weaker than that of key Cu-metalloproteins; (ii) a high $\mathrm{Cu}$ over $\mathrm{Zn}$ selectivity in order to mainly remove $\mathrm{Cu}$ and not $\mathrm{Zn}$, thus targeting the most toxic ion, at least with respect to ROS production; (iii) the redistribution approach adds value compared to the chelating one, indirectly inducing $A \beta$ degradation pathways; (iv) chelators or metallophores should form redox inert complexes to prevent ROS production. Directing the drug candidates towards $\mathrm{Cu}(\mathrm{I})$ or $\mathrm{Cu}(\mathrm{II})$ is still open to debate; but criteria (i) and (ii) may be easier to fulfill with $\mathrm{Cu}(\mathrm{I})$. 
Other points will have then to be taken into account, the most important of which is the ability to cross the blood-brain barrier (BBB) either via passive or active diffusion. ${ }^{114}$

Inorganic drugs. In addition to be used as prodrug (see §.Inorganic prodrug), inorganic complexes have been developed to target several aspects of AD (see eibc2499)..$^{90}$ Three main approaches can be found: (i) redistribution of $\mathrm{Cu}$ or $\mathrm{Zn}$ binding sites in the $A \beta$ (or ejection of them), (ii) inhibition of $A \beta$ aggregation, and (iii) secretase-like activity to cleave and clear $A \beta$ peptides.

Redistribution of the Cu and $\mathrm{Zn}$ binding site in the $A \beta$ peptide. The use of platinoid complexes with $\mathrm{N}$-heterocyclic and aromatic substituents aimed at precluding the binding of the $\mathrm{Cu}$ and $\mathrm{Zn}$ ions to the $A \beta$ peptide, considered as deleterious event in the $A D$ context, is a promising development in this area. Indeed such platinoid complexes make strong and relatively inert bond with the His residues from the peptide. ${ }^{90,115-117}$ But actually, it has been shown that they rather redistribute the $\mathrm{Cu}$ and/or $\mathrm{Zn}$ ion to another binding site in the peptide. ${ }^{118}$ This family of inorganic drugs mainly act by modulating the $A \beta$ aggregation pathways and in this family, the $\mathrm{Pt}(\mathrm{II})$ complex shown in Figure 9.a was studied in vivo, due its possible oral administration as the Pt(IV) prodrug, showing a decrease of amyloid deposits in transgenic mice models. ${ }^{119}$

a.

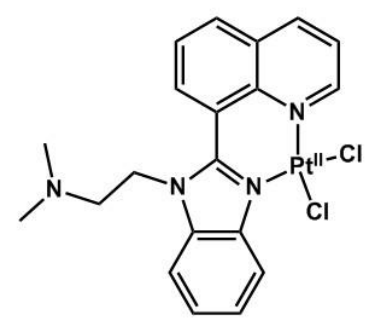

b.

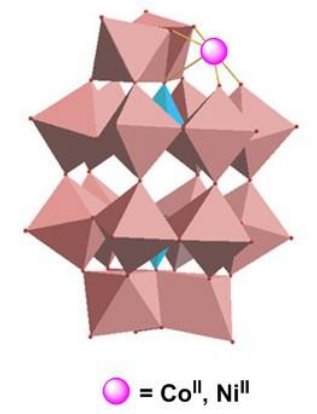

c.

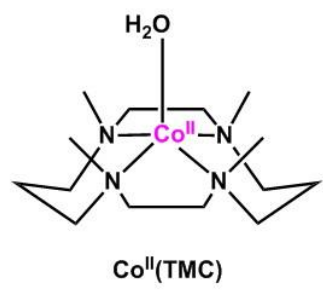

Figure 9. Inorganic drug candidates developed to fight AD.

Inhibition of $A \beta$ aggregation. POM (Poly-oxo metallates) including mono-substituted POM can inhibit $A \beta$ aggregation. This has been attributed to (i) POM binding to the peptide via electrostatic interaction that leads to monomer unable to aggregate and (ii) POM binding to oligomers leading to the stabilization of oligomers which is unfavorable for nucleation and growth of fibrils. ${ }^{120}$ The substitution by a Co(II) or Ni(II) ion (Figure 9.b) may increase the stability of the POM peptide interaction via binding of His residues to the metal center. ${ }^{121}$

Secretase-like activity. Another strategy relies on the use of azamacrocyles of transition metal ions (Figure 9.c) that has the ability to induce $A \beta$ hydrolysis and thus modulate its aggregation. Co(II) was shown to be the best metal center due to the low pKa value of the coordinated water molecule responsible for the hydrolytic activity. ${ }^{122}$ Having a synergetic effect by using the apo 
azamacrocyle ligand able to first remove $\mathrm{Cu}(\mathrm{II})$ and then use it to hydrolyze the peptide is also very elegant and has been reported with the cyclen-derivative ligand shown in Figure 6.b. ${ }^{103}$

Concluding remarks. While ligands (either chelators or metallophores) can influence ROS production and aggregation by removing the metal ions, inorganic drugs have a main impact on the aggregation process, which can however be different than the one obtained with the ligands. Hence the two approaches using organic or inorganic molecules seem to be complementary. Passage through the $\mathrm{BBB}$ may be more complex with the inorganic compounds than with the organic derivatives.

Inorganic detection agents. The early detection of $A D$ is the other key issue if one aims at effectively fighting the disease. Many organic molecules were reported, bearing either ${ }^{11} \mathrm{C}$ or ${ }^{18} \mathrm{~F}$ elements as radiotracers. ${ }^{19,123}$ The use of metal radionuclides is also of interest, mainly for the ease to generate the labelled molecule in comparison with the more challenging covalent incorporation of ${ }^{11} \mathrm{C}$ or ${ }^{18} \mathrm{~F}$ in organic scaffolds (see eibc.2447). In this context, mainly, ${ }^{99 \mathrm{~m} T c-}$ based molecules have been developed for SPECT imaging, with ${ }^{99 \mathrm{~m}} \mathrm{Tc}$ having an half-life of 6 hours and ${ }^{64} \mathrm{Cu}$ complexes for PET, with ${ }^{64} \mathrm{Cu}$ having an half-life of 13 hours. ${ }^{56,90}$ As a general trend, the ligand for the ${ }^{99 \mathrm{~m} T c}$ or ${ }^{64} \mathrm{Cu}$ ion is linked to an $A \beta$ recognition moiety, possibly via a modular linker (Figure 10.a), where two main $A \beta$ recognition moieties are used: the benzothiazole (Figure 10.b) or the stilbene scaffold (Figure 10.c). Affinity for the metal center and kinetic inertness of the resulting complex must be high to avoid any metal release. The complex shown in Figure 10.c is a typical thiosemicarbazone $\mathrm{Cu}(\mathrm{II})$ complex that was used to detect $A \beta$ deposits in post-mortem brains. ${ }^{124}$ Further improvements on the same scaffold lead to $\mathrm{CU}$ (II) complex able to cross the BBB in wild-type mice. ${ }^{125}$ Recently, a family of benzothiazole-azamacrocycle $\mathrm{Cu}(\mathrm{II})$ (Figure 10.b) complexes with the ability to be a leading family of molecules for diagnostic applications were also described. ${ }^{126}$ Indeed, promising results were obtained with respect to brain uptake in $A D$ transgenic model mice and preliminary imaging by microPET. ${ }^{127}$

a.

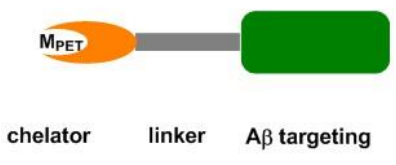

b.

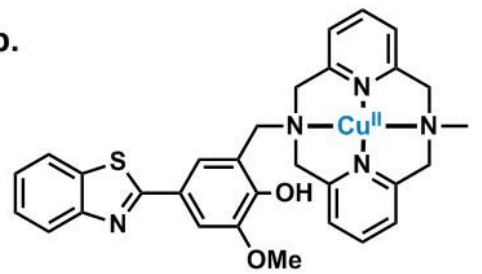

c.

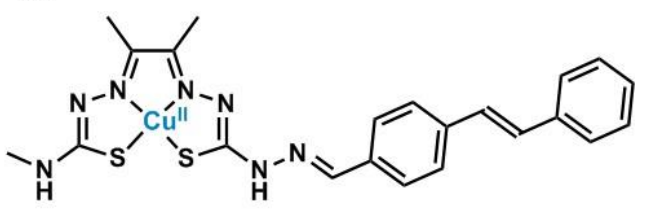

Figure 10. Radiotracers for early-detection of AD. General scheme of bifunctional chelator and corresponding ${ }^{64} \mathrm{Cu}(\mathrm{II})$ complexes.

Concluding remarks. AD early detection is crucial because late treatments are less (if not completely) inefficient. Hence, the future of any kind of radiotracers or imaging agents should focus on the design of molecules able to detect oligomeric states of the $A \beta$ aggregates. 


\section{What's next ?}

From my view as a bioinorganic chemist, metal ion binding to $A \beta$ is fascinating at several levels: the metal center ( $\mathrm{Cu}(\mathrm{I}), \mathrm{Cu}(\mathrm{II})$ or $\mathrm{Zn}(\mathrm{II}))$ drives the nature of the binding sites; the binding sites are not unique but several ones are possible and interconversion between them can be triggered by subtle changes (such as replacement of a non-binding Arg by a Gly residues in the murine sequence). One of the consequences of such versatility is the complex mechanism involved in ROS production and in modulation of the $A \beta$ aggregation pathways. Efforts to better decipher all of these metal related processes are essential if one aims at rationally designing new disease-modifying drugs. In addition, they have fostered the development of new spectroscopic tools and analytical methodologies that will be very useful in the future for the study of metal ions binding to other IDPs.

Since the 1990's and the proposition of the amyloid cascade hypothesis, therapeutics targeting the $A \beta$ peptide have been controverted because no curative drug candidates have succeeded in phase III of clinical trials. ${ }^{29}$ This is also true for molecules targeting metal ions linked to the amyloid cascade process. ${ }^{128}$ While as a direct consequence of such failures, the metal intervention in the amyloid cascade is more and more questioned, one may rather consider whether the metal-based therapeutic approaches developed were (biologically) relevant. Pathogenesis of AD is indeed multifactorial and only with respect to metal ions - $A B$ peptides interactions, the chemical partners are multiple. These include the different sequences of the $A \beta$, the various forms of $A \beta$ aggregates, the varying levels of $\mathrm{Cu}$ and $\mathrm{Zn}$, the presence of other amino-acid residues such as glutamate. Three examples illustrate this issue very well: (i) taking for granted that $\mathrm{Cu}(\mathrm{II})$ is the target of choice. The brain is a reducing environment and hence $\mathrm{Cu}(\mathrm{I})$ may be the main redox state of $\mathrm{Cu}$ ions within the synaptic cleft; 99 (ii) regarding $\mathrm{Zn}$ as an "innocent" ion because it is redox-silent. Indeed, $\mathrm{Zn}$ can interfere with $\mathrm{Cu}$ binding to the $A \beta$ peptides $^{129}$ and thus with $\mathrm{Cu}$ targeting; ${ }^{33}$ (iii) overlooking kinetic parameters in the design of chelators or metallophores. ${ }^{130}$ Up to now only thermodynamic data (affinity and selectivity) have been taken into account. As a more general trend, the importance of other biological partners have to be evaluated and a more general vision of $A D$ is required. This includes interaction of $A \beta$ with membranes ${ }^{131}$ and with Tau, while the two IDPs involved in the disease are currently considered independently when not opposed to each other. ${ }^{69}$ Another key issue may be the late detection of the disease that hampers any kind of modification of the disease progression. Here comes the question of prevention versus cure. To conclude with the therapeutic issues, one open question remains: do the metal and the amyloid cascade hypotheses need to be reassessed or should synthetic medicinal chemists be more creative ? 


\section{ABBREVIATIONS}

IDP: Intrinsically Disordered Peptides or Proteins ; $A D$ : Alzheimer's Disease ; $A \beta_{\mathrm{p} / \mathrm{q}-\mathrm{n} / \mathrm{m}}$ : $A \beta$ peptide starting at position $p$ or $q$ and ending at position $n$ or $m$; ROS: Reactive Oxygen Species ; FAD: Familial Alzheimer's Disease ; ThT: Thioflavin T ; ATCUN: Amino-Terminal Cu and Ni binding motif ; BBB: Blood Brain Barrier.

\section{ACKNOWLEDGEMENTS}

I acknowledge all the people I had the chance to work with during the last years and my current coworkers. I would like to thank specifically Amandine Conte-Daban, Elena Atrian-Blasco and Xudong Lin, with whom I have written several review articles that were very useful for the redaction of the present chapter. Funding by the European Research Council (ERC StG 638712 - aLzINK) is also warmly acknowledged.

\section{REFERENCES}

1. V. N. Uversky, Adv. Protein Chem. Struct. Biol. , 2018, 110, 85.

2. M. Korsak and T. Kozyreva, Adv. Exp. Med. Biol., 2015, 870, 401.

3. R. Riek and D. S. Eisenberg, Nature (London), 2016, 539, 227.

4. W. Pulawski, U. Ghoshdastider, V. Andrisano and S. Filipek, Appl. Biochem. Biotechnol., 2012, $166,1626$.

5. S. S. Leal, H. M. Botelho and C. M. Gomes, Coord. Chem. Rev., 2012, 256, 2253.

6. L. Breydo and V. N. Uversky, Metallomics, 2011, 3, 1163.

7. P. Faller, C. Hureau and G. La Penna, Acc. Chem. Res., 2014, 47, 2252.

8. H. Kozlowski, M. Luczkowski, M. Remelli and D. Valensin, Coord. Chem. Rev., 2012, 256, 2129.

9. E. Atrian-Blasco, P. Gonzalez, A. Santoro, B. Alies, P. Faller and C. Hureau, Coord. Chem. Rev., 2018, revision.

10. C. Cheignon, M. Tomas, D. Bonnefont-Rousselot, P. Faller, C. Hureau and F. Collin, Redox Biology, 2018, 14, 450.

11. A. P. Lan, J. Chen, Z. F. Chai and Y. Hu, Biometals, 2016, 29, 665.

12. C. Garza-Lombo, Y. Posadas, L. Quintanar, M. E. Gonsebatt and R. Franco, Antioxid Redox Signal., 2018, in press.

13. J. Li, W. O, W. Li, Z.-G. Jiang and H. A. Ghanbari, Int. J. Mol. Sci. , 2013, 14, 24438.

14. F. U. Hartl, A. Bracher and M. Hayer-Hartl, Nature (London), 2011, 475, 324.

15. D. M. Holtzman, J. C. Morris and A. M. Goate, Sci. Transl. Med., 2011, 3, 77sr1.

16. C. A. Lana, J. Hardy and J. M. Schott, Eur. J. Neurol., 2018, 25, 59.

17. J. Gaugler, B. James, T. Johnson and J. Weuve, Alzheimers Dementia, 2017, 13, 325.

18. C. Li and J. Götz, Nat. Rev. Drug Discov., 2017, 12, 863.

19. V. L. Villemagne, V. Doré, S. C. Burnham, C. L. Masters and C. C. Rowe, Nature Review Neurology, 2018, doi: 10.1038/nrneurol.2018.9. .

20. J. C. Polancon, C. Li, L. G. Bodea, R. Martinez-Marmol, F. A. Meunier and J. Götz, Nature Review Neurology, 2018, 14, 22.

21. R. Aleksis, F. Oleskovs, K. Jaudzems, J. Pahnke and H. Biverstål, Biochimie, 2017, 140, 176.

22. C. Hureau, Coord. Chem. Rev., 2012, 256, 2164.

23. V. Tôugu and P. Palumaa, Coord. Chem. Rev., 2012, 256, 2219.

24. V. Tôugu and P. Palumaa, Metallomics, 2011, 3, 250.

25. M. d. C. Cárdenas-Aguayo, M. d. C. Silva-Lucero, M. Cortes-Ortiz, B. Jiménez-Ramos, L. Gómez-Virgilio, G. Ramírez-Rodríguez, E. Vera- Arroyo, R. Fiorentino-Pérez, U. García, J. LunaMuñoz and M. A. Meraz-Ríos, in Neurochemistry, ed. I.-..-.-. Thomas Heinbockel, 2014, vol. Chapter 9. 
26. T. H. Xu, Y. Yan, Y. Kang, Y. Jiang, K. Melcher and H. E. Xu, Cell Discovery, 2016, 2, 16026.

27. C. Hureau and P. Dorlet, Coord. Chem. Rev., 2012, 256, 2175.

28. I. Sóvágó, C. Kállay and K. Várnagy, Coord. Chem. Rev., 2012, 256, 2225.

29. E. Karran, M. Mercken and B. De Strooper, Nature Reviews 2011, 10, 698.

30. E. Atrián-Blasco, A. Santoro, D. L. Pountney, G. Meloni, C. Hureau and P. Faller, Chem. Soc. Rev., 2017, 46, 7683.

31. J. S. Cristóvão, R. Santos and C. M. Gomes, Oxid. Med. Cell. Longev., 2016, 2016, 9812178.

32. S. C. Drew and K. J. Barnham, Acc. Chem. Res., 2011, 44, 1146.

33. E. Atrian-Blasco, A. Conte-Daban and C. Hureau, Dalton Transactions, 2017, 46, 12750.

34. V. Borghesani, B. Alies and C. Hureau, Eur. J. Inorg. Chem., 2018, 7.

35. W. Bal, M. Sokołowska, E. Kurowska and P. Faller, Biochim. Biophys. Acta, 2013, 1830, 5444.

36. P. Gonzalez, K. Bossak, E. Stefaniak, C. Hureau, L. Raibaut, W. Bal and P. Faller, Chem. Eur. J., 2018 , in press.

37. T. Branch, P. Girvan, M. Barahona and L. Ying, Angewandte Chemie International Edition, 2015, asap.

38. J. T. Pedersen, K. Teilum, N. H. H. Heegaard, J. Østergaard, H.-W. Adolph and L. Hemmingsen, Angew. Chem., Int. Ed. Engl., 2011, 50, 2532.

39. J. T. Pedersen, C. B. Borg, T. C. Michaels, T. P. Knowles, P. Faller, K. Teilum and L. Hemmingsen, ChemBioChem, 2015, 16, 1293.

40. P. Girvan, T. Miyake, X. Teng, T. Branch and L. Ying, ChemBioChem, 2016, 17, 1732.

41. J. Shearer and V. A. Szalai, J. Am. Chem. Soc., 2008, 130, 17826.

42. C. Hureau, V. Balland, Y. Coppel, P. L. Solari, E. Fonda and P. Faller, J. Biol. Inorg. Chem., 2009, 995.

43. Z. Xiao, L. Gottschlich, R. van der Meulen, S. R. Udagedara and A. G. Wedd, Metallomics, 2013, 5, 501.

44. T. R. Young, A. Kirchner, A. G. Wedd and Z. Xiao, Metallomics, 2014, 6, 505.

45. B. Alies, B. Badei, P. Faller and C. Hureau, Chem. Eur. J., 2012, 18, 1161.

46. C. Migliorini, E. Porciatti, M. Luczkowski and D. Valensin, Coord. Chem. Rev., 2012, 256, 352.

47. B. Alies, A. Conte-Daban, S. Sayen, F. Collin, I. Kieffer, E. Guillon, P. Faller and C. Hureau, Inorg. Chem., 2016, 55, 10499.

48. E. Gaggelli, A. Janicka-Klos, E. Jankowska, H. Kozlowski, C. Migliorini, E. Molteni, D. Valensin, G. Valensin and E. Wieczerzak, J. Phys. Chem. B., 2008, 112, 100.

49. S. A. Kozin, A. A. Kulikova, A. N. Istrate, P. O. Tsvetkov, S. S. Zhokhov, Y. V. Mezentsev, O. I. Kechko, A. S. Ivanov, V. I. Polshakov and A. A. Makarov, Metallomics, 2015, 7, 422.

50. V. I. Polshakov, A. B. Mantsyzov, S. A. Kozin, A. A. Adzhubei, S. S. Zhokhov, W. van Beek, A. A. Kulikova, M. I. Indeykina, V. A. Mitkevich and A. A. Makarov, Angewandte Chemie International Edition, 2017, in press.

51. L. Xu, Y. Chen and X. Wang, Proteins, 2014, 82, 3286.

52. S. Noël, S. Bustos, S. Sayen, E. Guillon, P. Faller and C. Hureau, Metallomics, 2014, 6, 1220.

53. I. Zawisza, M. Rozga and W. Bal, Coord. Chem. Rev., 2012, 256, 2297.

54. V. Balland, C. Hureau and J.-M. Savéant, Proc. Natl. Acad. Sci. U. S. A., 2010, 107, 17113.

55. C. Cheignon, M. Jones, E. Atrian-Blasco, I. Kieffer, P. Faller, F. Collin and C. Hureau, Chemical Science, 2017, 8, 5107.

56. S. Noël, S. Cadet, E. Gras and C. Hureau, Chem. Soc. Rev., 2013, 42, 7747.

57. G. Meisl, J. B. Kirkegaard, P. Arosio, T. C. Michaels, M. Vendruscolo, C. M. Dobson, S. Linse and T. P. Knowles, Nature Protocols, 2016, 11, 252.

58. C. P, M. A. Sani, F. Ding, A. Kakinen, I. Javed, F. Separovic, T. P. Davis and R. Mezzenga, Chem. Soc. Rev., 2017, 46, 6492.

59. B. Alies, C. Hureau and P. Faller, Metallomics, 2013, 5, 183.

60. P. Faller, C. Hureau and O. Berthoumieu, Inorg. Chem., 2013, 52, 12193.

61. F. Hane and Z. Leonenko, Biomolecules, 2014, 4, 101.

62. J. H. Viles, Coord. Chem. Rev., 2012, 256, 2271. 
63. K. L. Stewart and S. E. Radford, Biophysical Reviews, 2017, 9, 405.

64. L. Gremer, D. Schölzel, C. Schenk, E. Reinartz, J. Labahn, R. B. G. Ravelli, M. Tusche, C. LopezIglesias, W. Hoyer, H. Heise, D. Willbold and G. F. Schröder, Science (Washington, D. C., 1883), 2017, 358, 116.

65. M. A. Wälti, F. Ravotti, H. Arai, C. G. Glabe, J. S. B. Wall, A., P. Güntert and B. H. R. Meier, R. , Proc. Natl. Acad. Sci. U. S. A., 2016, \&\&", E4976.

66. M. T. Colvin, R. Silvers, Q. Z. Ni, T. V. Can, I. Sergeyev, M. Rosay, K. J. Donovan, B. Michael, J. Wall, S. Linse and R. G. Griffin, J. Am. Chem. Soc., 2016, 138, 9663.

67. P. Faller and C. Hureau, Dalton Trans., 2009, 1080.

68. M. G. Savelieff, S. Lee, Y. Liu and M. H. Lim, ACS Chem. Biol., 2014, 8, 856.

69. F. Kametani and M. Hasegawa, Front. Neurosci. , 2018, 12, 25.

70. E. Valera, B. Spencer and E. Masliah, Neurotherapeutics, 2016, 13, 179.

71. A. Binolfi, L. Quintanar, C. W. Bertoncini, C. Griesinger and C. O. Fernández, Coord. Chem. Rev., 2012, 256, 2188.

72. D. J. Irwin, V. M. Lee and J. Q. Trojanowski, Nat. Rev. Neurosci., 2013, 14, 626.

73. M. Goedert, Science (Washington, D. C., 1883-), 2015, 349, 1255555.

74. C. Ugalde, D. I. Finkelstein, V. A. Lawson and A. F. Hill, J. Neurochem., 2016, 139, 162.

75. R. Tycko and R. B. Wickner, Acc. Chem. Res., 2013, 46, 1487.

76. G. Arena, D. La Mendola, G. Pappalardo, I. Sóvágó and E. Rizzarelli, Coord. Chem. Rev., 2012, 256, 2202.

77. G. Hoffner and P. Djian, Mol. Neurobiol., 2015, 52, 1297.

78. K. J. Barnham and A. I. Bush, Chem. Soc. Rev., 2014, 43, 6727.

79. V. K. C. Mulligan, A., Proteins, 2013, 81, 1285.

80. J. Costa, C. Gomes and M. de Carvalho, CNS Neurol. Disord. Drug. targets, 2010, 9, 764.

81. J. R. Brender, S. Salamekh and A. Ramamoorthy, Acc. Chem. Res., 2012, 45, 454.

82. P. Westermark, A. Andersson and G. T. Westermark, Physiol. Rev., 2011, 91, 795.

83. A. S. DeToma, S. Salamekh, A. Ramamoorthy and M. H. Lim, Chem. Soc. Rev., 2012, 41, 608.

84. A. Robert, Y. Liu, M. Nguyen and B. Meunier, Acc. Chem. Res., 2015, 48, 1332.

85. V. B. Kenche and K. J. Barnham, Br. J. Pharmacol., 2011, 163, 211.

86. L. E. Scott and C. Orvig, Chem. Rev., 2009, 109, 4885.

87. M. A. Telpoukhovskaia and C. Orvig, Chem. Soc. Rev., 2013, 42, 1836.

88. P. J. Crouch and K. J. Barnham, Acc. Chem. Res., 2012, 45, 1604.

89. J. S. Derrick and M. H. Lim, ChemBioChem, 2015, 16, 887.

90. D. J. Hayne, S. Lim and P. S. Donnelly, Chem. Soc. Rev., 2014, 43, 6701.

91. M. G. Savelieff, A. S. DeToma, J. S. Derrick and M. H. Lim, Acc. Chem. Res., 2014, 47, 2475.

92. C. Rodriguez-Rodriguez, M. Telpoukhovskaia and C. Orvig, Coord. Chem. Rev., 2012, 256, 2308.

93. M. A. Santos, K. Chand and S. Chaves, Coord. Chem. Rev., 2016, 327-328, 287.

94. T. Chen, X. Wang, Y. He, C. Zhang, Z. Wu, K. Liao, J. Wang and G. Zijian, Inorg. Chem., 2009, 48, 5801.

95. T. Storr, M. Merkel, G. X. Song-Zhao, L. E. Scott, D. E. Green, M. L. Bowen, K. H. Thompson, B. O. Patrick, H. J. Schugar and C. Orvig, J. Am. Chem. Soc., 2007, 129, 7453.

96. A. Conte-Daban, A. Day, P. Faller and C. Hureau, Dalton Transactions, 2016, 45, 15671.

97. A. B. Caballero, L. Terol-Ordaz, A. Espargaró, G. Vázquez, E. Nicolás, R. Sabaté and P. Gamez, Chem. Eur. J., 2015, 22, 7268.

98. E. Atrian-Blasco, E. Cerrada, A. Conte-Daban, D. Testemale, P. Faller, M. Laguna and C. Hureau, Metallomics, 2015, 7, 536.

99. A. Conte-Daban, B. Boff, A. Candido Matias, C. N. Montes Aparicio, C. Gateau, C. Lebrun, G. Cerchiaro, I. Kieffer, S. Sayen, E. Guillon, C. Hureau and P. Delangle, Chem. Eur. J., 2017, 23, 17078.

100. A. K. Sharma, S. T. Pavlova, J. Kim, D. Finkelstein, N. J. Hawco, N. P. Rath, J. Kim and L. M. Mirica, J. Am. Chem. Soc., 2012, 134, 6625. 
101. J.-S. Choi, J. J. Braymer, R. P. R. Nanga, A. Ramamoorthy and M. H. Lim, Proc. Natl. Acad. Sci. U. S. A., 2010, 107, 21990.

102. M. W. Beck, S. B. Oh, R. A. Kerr, H. J. Lee, S. H. Kim, S. Kim, M. R. Jang, Brandon T. , J.-Y. Lee and M. H. Lim, Chemical Science, 2015, 6, 1879.

103. W. H. Wu, P. Lei, Q. Liu, J. Hu, A. P. Gunn, M. S. Chen, Y. F. Rui, X. Y. Su, Z. P. Xie, Y. F. Zhao, A. I. Bush and Y. M. Li, J. Biol. Chem., 2008, 283, 31657.

104. M. R. Jones, E. Mathieu, C. Dyrager, S. Faissner, Z. Vaillancourt, K. J. Korshavn, M. H. Lim, A. Ramamoorthy, V. Wee Yong, S. Tsutsui, P. K. Stys and T. Storr, Chem. Sci. , 2017, 8, 5636.

105. V. Oliveri and G. Vecchio, Eur. J. Med. Chem., 2016, 120, 252.

106. V. L. Villemagne, C. C. Rowe, K. J. Barnham, R. Cherny, M. Woodward, S. Bozinosvski, O. Salvado, P. Bourgeat, K. Perez, C. Fowler, A. Rembach, P. Maruff, C. Ritchie, R. Tanzi and C. L. Masters, Alzheimers Dementia, 2017, 3, 622.

107. P. J. Crouch, M. S. Savva, L. W. Hung, P. S. Donnelly, A. I. Mot, S. J. Parker, M. A. Greenough, I. Volitakis, P. A. Adlard, R. A. Cherny, C. L. Masters, A. I. Bush, K. J. Barnham and A. R. White, J. Neurochem., 2011, 119, 220.

108. P. S. Donnelly, A. Caragounis, T. Du, K. M. Laughton, I. Volitakis, R. A. Cherny, R. A. Sharples, A. F. Hill, Q. X. Li, C. L. Masters, K. J. Barnham and A. R. White, J. Biol. Chem., 2008, 282, 4568.

109. M. Nguyen, C. Bijani, N. Martins, B. Meunier and A. Robert, Chem. Eur. J., 2015, 21, 17085.

110. V. Oliveri and G. Vecchio, J. Inorg. Biochem., 2016, 162, 31.

111. D. S. Folk and K. J. Franz, J. Am. Chem. Soc., 2010, 132, 4994.

112. H. Schugar, D. E. Green, M. L. Bowen, L. E. Scott, T. Storr, K. Böhmerle, F. Thomas, D. D. Allen, P. R. Lockman, M. Merkel, K. H. Thompson and C. Orvig, Angewandte Chemie International Edition, 2007, 4-, 1716.

113. A. Conte-Daban, V. Ambike, R. Guillot, N. Delsuc, C. Policar and C. Hureau, Chem. Eur. J., 2018, https://doi.org/10.1002/chem.201706049.

114. N. J. Abbott, J. Inherit. Metab. Dis., 2013, 3-, 437.

115. D. Valensin, C. Gabbiani and L. Messori, Coord. Chem. Rev., 2012, 19-20, 2357.

116. A. Spinello, R. Bonsignore, G. Barone, B. K. Keppler and A. Terenzi, Curr. Pharm. Des., 2016, 22, 3996.

117. J. J. Miller, L. M. F. Gomes, T. Storr and A. Casini, in Encyclopedia of Inorganic and Bioinorganic Chemistry, Wiley, 2017, pp. 1.

118. F. Collin, I. Sasaki, H. Eury, P. Faller and C. Hureau, Chem. Commun., 2013, 49, 2130.

119. V. B. Kenche, L. W. Hung, K. Perez, I. Volitakes, G. Ciccotosto, J. Kwok, N. Critch, N. Sherratt, M. Cortes, V. Lal, C. L. Masters, K. Murakami, R. Cappai, P. A. Adlard and K. J. Barnham, Angew. Chem. Int. Ed., 2013, 52, 3374.

120. J. Geng, M. Li, J. Ren, E. Wang and X. Qu, Angewandte Chemie International Edition, 2011, 50, 4184.

121. N. Gao, H. Sun, K. Dong, J. Ren, T. Duan, C. Xu and X. Qu, Nature Communication, 2014, 4, 3422.

122. J. S. Derrick, J. Lee, S. J. C. Lee, Y. Kim, E. Nam, H. Tak, J. Kang, M. Lee, S. H. Kim, K. Park, J. Cho and M. H. Lim, J. Am. Chem. Soc., 2017, 139, 2234.

123. K. Pietrzak, K. Czarnecka, E. Mikiciuk-Olasik and P. Szymanski, Med. Chem. , 2018, 14, 34.

124. S. Lim, B. M. Paterson, M. T. Fodero-Tavoletti, G. J. O'Keefe, R. Cappai, K. J. Barnham, V. L. Villemagne and P. S. Donnelly, Chem. Commun., 2010, 46, 5437.

125. J. L. Hickey, S. Lim, D. J. Hayne, B. M. Paterson, J. M. White, V. L. Villemagne, P. Roselt, D. Binns, C. Cullinane, C. M. Jeffery, R. I. Price, K. J. Barnham and P. S. Donnelly, J. Am. Chem. Soc., 2013, 135, 16120.

126. A. K. Sharma, J. W. Schultz, J. T. Prior, N. P. Rath and L. M. Mirica, Inorg. Chem., 2017, 56, 13801.

127. N. Bandara, A. K. Sharma, S. Krieger, J. W. Schultz, B. H. Han, B. E. Rogers and L. M. Mirica, J. Am. Chem. Soc., 2017, 139, 12550.

128. S. C. Drew, Front. Neurosci., 2017, 11, 317. 
129. B. Alies, I. Sasaki, O. Proux, S. Sayen, E. Guillon, P. Faller and C. Hureau, Chem. Commun., 2013, 49, 1214.

130. A. Conte-Daban, M. Beyler, R. Tripier and C. Hureau, Chem. Eur. J., 2018, https://doi.org/10.1002/chem.201801520.

131. A. D. Watt, V. L. Villemagne and K. J. Barnham, J Alzheimers Dis., 2013, 33, S283.

\section{ABSTRACT}

In the present chapter, I review the structural, thermodynamic and kinetic data on metal ions (copper and zinc) binding to the amyloid- $\beta$ peptides of various sequences involved in Alzheimer's disease. Metal ions are indeed regarded as key players in Alzheimer's disease because they may contribute to the oxidative stress and modulate the aggregation propensity of the amyloid- $\beta$ peptides, two key processes in the etiology of the disease. An analogy with the influence of the interaction between metal ions and other intrinsically disordered peptides in different pathologies is also drawn. In a second part, several therapeutic and diagnostic approaches based on the role of metal ions are described and discussed. A selection of chelators, metallophores, prodrugs as well as inorganic compounds is proposed that illustrates the various strategies developed by inorganic medicinal chemists to fight Alzheimer's disease.

\section{KEYWORDS}

Intrinsically disordered peptide / amyloid- $\beta$ / Alzheimer's disease / Reactive Oxygen Species / Aggregation / therapeutic approaches 